Case Report

\title{
Biocontrol of Crown Gall by Rhizobium rhizogenes: Challenges in Biopesticide Commercialisation
}

\author{
Allen Kerr ${ }^{1}$ and Gary Bullard ${ }^{2, *}$ \\ 1 Department of Plant Pathology, University of Adelaide, Adelaide, SA 5064, Australia; kerra@senet.com.au \\ 2 Bio-Care Technology Pty Ltd., Myocum, NSW 2481, Australia \\ * Correspondence: info@bio-caretechnology.com
}

Received: 18 June 2020; Accepted: 30 July 2020; Published: 3 August 2020

\begin{abstract}
The biocontrol of crown gall has been practised in Australia for 48 years. Control is so efficient that it is difficult to find a galled stone fruit tree, when previously, crown gall had been a major problem. This paper explains how it works and why only pathogens are inhibited. A commercial biopesticide is available in Australia, Canada, Chile, New Zealand, Turkey, the USA, South Africa and Japan. The challenges of commercialising a biopesticide are outlined. Rigid regulations are preventing the wider use of biocontrol organisms.
\end{abstract}

Keywords: crown gall; Agrobacterium; Rhizobium; agrocin 84; TM84; agrocinopine; biopesticide

\section{Introduction}

Crown gall is caused by soil-inhabiting bacteria that transfer some of their DNA to plant cells [1], which, as a result, grow and divide out of control to form galls or tumours. The tumour-inducing genes are located on a plasmid, pTi [1]. A recent review describes, in detail, the infection process [2]. Infection may occur through wounds or lenticels [3]. An efficient biocontrol agent should be able to colonise both sites.

\section{Biocontrol}

In Australia, crown gall (Figure 1) of several plant species has been controlled biologically since the 1970s [4]. The control organism is strain K84, a biovar 2 strain of Agrobacterium radiobacter (now Rhizobium rhizogenes) and an efficient root coloniser [5].

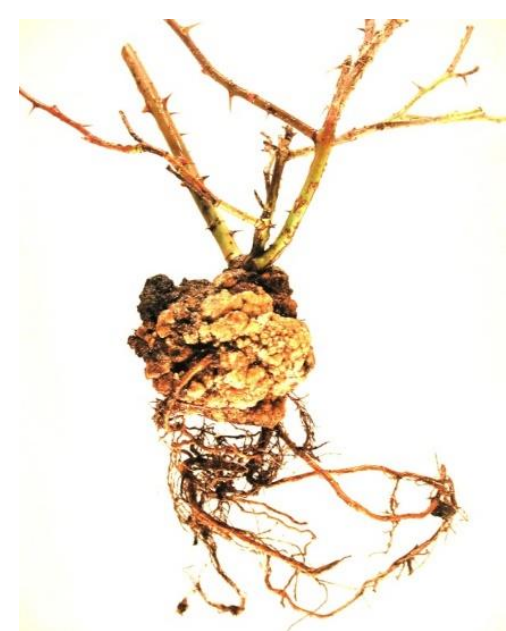

Figure 1. Crown gall on rose (provided by Melodie Putnam). 
Initially, the inoculant was supplied by the scientific laboratory that isolated K84, but later, a commercial product, containing strain K1026, a modified version of strain K84, was produced [6] and registered as a biopesticide in 1988 (Australia), 2000 (USA) and 2005 (Turkey). Control occurs through the production of an antibiotic, agrocin 84 [7] (Figure 2). It is an adenine nucleotide with two substituents, one of which controls uptake and the other, toxicity [8]. Agrocin 84 prevents protein synthesis by inhibiting the essential enzyme leucyl tRNA synthetase $[9,10]$.

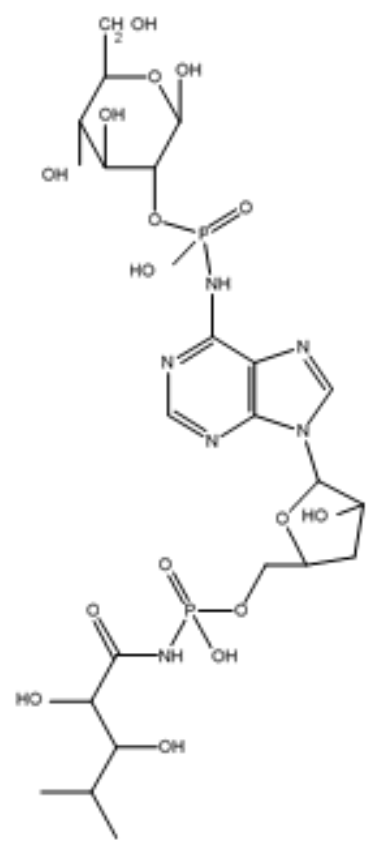

Figure 2. Agrocin 84 in N-6 $\beta$-D-Glucopyranosyl-form (provided by the late Max Tate).

Genes for the synthesis of agrocin 84 are located on a plasmid, pAgK84 [11], a conjugative plasmid that can be transferred to other strains, including pathogens [12]; it also carries immunity to agrocin $84[13,14]$. To prevent transfer, the transfer genes were located [13] and a transfer-minus deletion mutant was constructed [6] to produce strain K1026. As restriction enzymes and a ligase were used to construct K1026, it was originally designated a GMO, a genetically modified organism. However, as it is a deletion mutant and contains no foreign DNA, it is no longer considered as such in most countries. The system has at least two very interesting features: only pathogens are inhibited by the antibiotic so there is no damage to the environment, and the system has been used commercially for about 48 years but there is no evidence of resistance to agrocin 84 developing. Control is so effective that in Australia, it is difficult to find crown gall on roses and stone fruit trees when once, it was a major problem. The biocontrol of crown gall probably contributes about 100 million Australian dollars (AUD) annually to the Australian economy.

Crown galls contain unusual compounds, now called opines, found nowhere else in the plant kingdom [15]. They are used as nutrients by the inciting bacteria, and they alone can utilise them. Agrocin 84 is a Trojan Horse antibiotic because it uses a bacterial uptake system designed for the uptake of an opine, agrocinopine A [16,17] (Figure 3). 


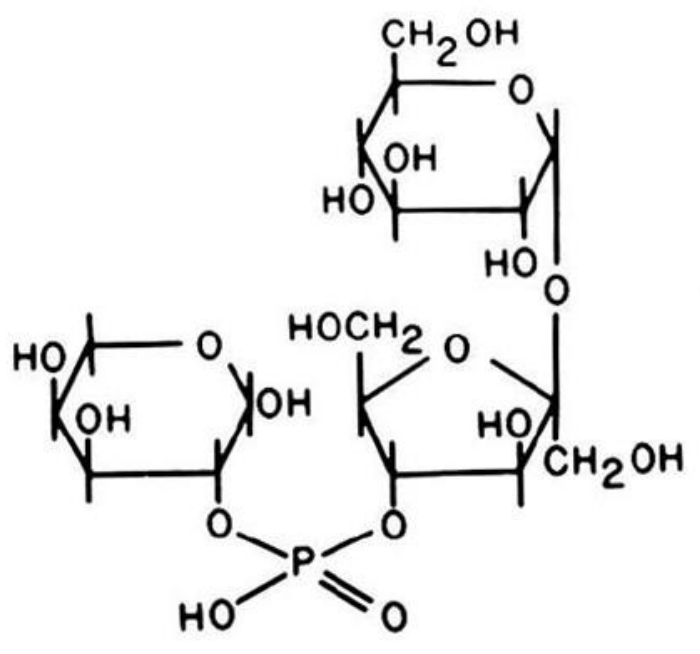

Figure 3. Agrocinopine A (provided by Maarten Ryder).

The genetics of the system have been established by Stephen Farrand's group [18], and the uptake mechanism, by the Morera and Reader labs [19], where a pyranase-2-phosphate motif, present in both agrocin 84 and agrocinopine A, is all important. As opines can only be utilised by crown gall pathogens, only pathogens are inhibited. Agrocin 84 is a pro-drug because after entering a cell, it is processed to remove the sugar $[9,10]$ and form a toxic moiety, TM84. Why resistance has not developed is unknown, although the fact that strains K84 and K1026 also produce agrocin 434 [20] might be significant. The commercial biopesticide controls crown gall on stone fruits, nut trees, roses and several other crops but not all, notably on grapevines where crown gall is caused by strains resistant to agrocin 84. Attempts to develop a commercial biocontrol for grapevine crown gall continue [21,22].

It should be noted that in crown gall, the control organism is closely related to the pathogen. Perhaps more attention should be paid to close relatives when seeking new biopesticides [23]. Importantly, the identification of agrocin 84 as a potent leucyl tRNA synthetase inhibitor has heralded the discovery of other Trojan Horse aminoacyl tRNA synthetase inhibitors. This novel class of natural antimicrobials constitutes rational platforms for the development of pro-drugs that may be tailored to specifically target human pathogens and selectively inhibit 20 different essential aminoacyl tRNA synthetases [24].

\section{Challenges of Biopesticide Commercialisation-Case Study of K84 and K1026}

The discovery and development of strains K84 and K1026 for the biocontrol of crown gall disease was a significant achievement for helping propagation nurseries battling with this disease worldwide. Moving from the discovery and testing in the research phase, to delivering commercial biocontrol agents to the marketplace, encompasses many challenges [25-27]. Just as the time and efforts involved in the initial phase of research take years of dedicated commitment, so does the commercial development phase. The following outlines some examples of these challenges as they relate to strains K84 and K1026. The cancerous plant disease crown gall has no effective chemical control, so biocontrol is the only way to prevent disease epidemics and reduce economic losses in certain crops. The commercial release of K84 in the 1970s made it the first registered biopesticide for the biocontrol of a soil-borne plant disease.

Research institutions, with biocontrol technologies ready for the market, ultimately need to go through the process of linking their research to commercial partnerships, often with small-medium sized enterprises (SME). In the case of Rhizobium rhizogenes, strain K84, cultures were provided "free-of-charge" during 1973-1974 to anyone that wanted to test or commercialise the bacterium. By 1974, two companies in Australia had started producing pure cultures of K84 as either agar cultures in Roux bottles or pure, peat-based inoculants for supply to nurseries across Australia. Cultures were 
also sent to colleagues in various parts of the world during the 1970s with no contractual agreements. No patents were ever applied for on K84 or its use, so it was publicly available. During the following years from the initial release of K84, several researchers outside Australia tested K84 and/or K1026 against local, pathogenic Agrobacterium in various countries in the world (Figure 4).

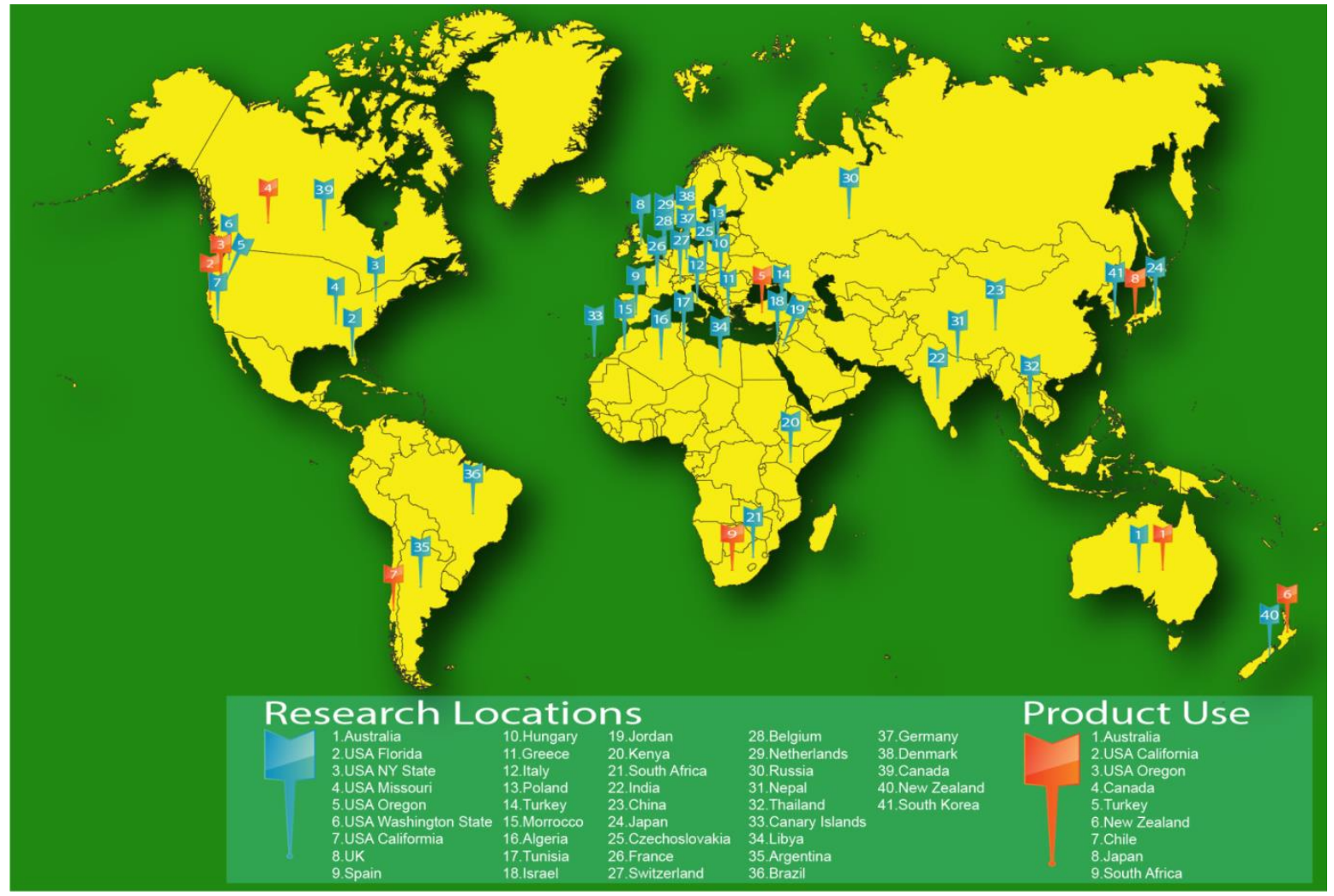

Figure 4. Product distribution and research locations for K84 or K1026.

After K1026 was developed, Luminis Pty Ltd. (U Adelaide) granted an exclusive license for its commercial use to Bio-Care Technology Pty Ltd. (Sydney, Australia) in 1988, and patents were lodged and approved in Australia, the USA and some European countries (1994) [28]. Cultures of K84 continued to be sold in competition with K1026 as well as being supplied by some laboratories or local agricultural experiment stations for research, but any sale of these cultures was illegal in all jurisdictions that require plant protection products (PPP) to be government-registered as biopesticides.

\subsection{Government Registrations}

Like all commercial pesticides, microbial pest control agents (MPCA) and their end-use products (EUP) must go through a detailed evaluation by government regulatory agencies before transport, distribution and sale to prove they are effective and safe for humans, plants, non-target organisms and the environment [29-31]. K84 and K1026 are closely related to a ubiquitous group of agrobacteria that have been isolated by microbiologists in soils on every continent [32]. Regardless of the ubiquitous and non-pathogenic nature of these soil bacteria, K84 and K1026 went through stringent assessment processes in several countries before either was approved as safe for commercial use.

By 1975, K84 was registered as a biopesticide with several states in Australia and in New Zealand (NZ). In Australia, K84 remained commercially available until December 1988 when K1026 was reviewed and approved for sale in the product NOGALL ${ }^{{ }^{\mathrm{TM}}}$, Woy Woy, New South Wales (NSW), Australia, by the NSW Department of Agriculture. The sale of K1026's EUP marked the world's first live genetically engineered (or modified) organism to be publicly available. In May 1993, a submission for the commercial use of K1026, in the product NOGALL, was approved nationally by the Australian 
Agricultural Veterinary Chemicals Council, the Genetic Manipulation Advisory Committee and the Office of Gene Technology Regulator. Their decisions were to exempt K1026 from regulations outlined in the federal government legislation; hence, K1026 was not classified as a regulated, genetically engineered organism $[33,34]$.

In 1996, a framework for the scientific evaluation of the biosafety of microorganisms intended for pest and plant disease control in the USA was submitted for commentary [35]. This review highlights the various aspects in the safety testing of MPCAs and lists the biopesticides registered in the USA at that time. In the USA, the Environmental Protection Agency (EPA) regulates submissions for biopesticide registrations through the Microbial Pesticides Branch/Biopesticides and Pollution Prevention Division/Office of Pesticide Programs [36]. Federal regulations required studies and reports on the active ingredients, K84 or K1026, relating to:

1. Identification and characterisation assessments;

2. A description of gene deletions and lineage to K84 (K1026);

3. Human health risk assessments (pathogenicity, toxicity, allergenicity, sensitisation and mutagenicity);

4. Target organism effects (mode of action);

5. Non-target organism effects;

6. Environmental risk assessment.

In addition, the EUP evaluation involved data to support:

1. A statement of formula;

2. A certificate of analysis on samples from several production batches;

3. Physical and chemical properties;

4. Storage stability;

5. The efficacy of the biological control product;

6. Label wording and claims;

7. Risk management.

For the K1026 and EUP submission to the EPA, applicable studies and data collection to satisfy each Federal Insecticide, Fungicide and Rodenticide (FIFRA) 40 Code of Federal Regulations (CFR) 158:2100 criterion took 8 years to organise with several interruptions during this period. Then, after submitting the applications, there were additional studies required, which took another year and a half to complete. In September 1999, the EPA approved the "conditional" registration of K1026 and NOGALL. Full registration by the EPA was completed in 2001 after nearly 11 years in the process.

Besides the EPA approval, K84 and K1026 products need to obtain registration approvals with each state in the USA in which they are intended to be distributed and sold. Most states accept the US EPA approvals and issue registration certificates for periods ranging from 12 to 24 months. However, the California Department of Pesticide Regulations reviews submissions differently and is the most difficult state in which to gain approval. NOGALL, containing K1026, was "conditionally" registered in California in September 2000 pending the submission and review of five additional studies before final approval, which was achieved in 2001.

During 2009-2012, all K84 and K1026 products in the USA went through a re-registration review to comply with the Food Quality Protection Act (FQPA) of 1996 and FIFRA regulations contained in 40 CFR 155.57. These regulations mandate the continuous review of existing, registered pesticides every 15 years to determine whether the pesticides continue to meet the statutory standard of no unreasonable adverse effects on human health or the environment. In 2012, the EPA issued approval for A. radiobacter K84/Kerr-84 and K1026 under this program [37].

In addition to the initial submission to the EPA for K1026 registration, an application was also lodged with the Animal and Plant Health Inspection Service (APHIS) of the United States Department of Agriculture (USDA) to determine if K1026 required a Plant Protection and Quarantine (PPQ) 526 
permit for the importation, interstate movement and environmental release of biological control organisms for plant pests. The APHIS review resulted in the issuance of a declaration stating K1026 was not regulated under the Plant Protection and Honeybee Acts and no PPQ 526 was necessary. However, the APHIS did issue a permit with certain conditions for the clearance of the K1026 product on arrival, through customs clearance, movement to the destination agent in the USA and final distribution to nurseries.

In 2005, a Dossier application for registration of NOGALL ${ }^{\mathrm{TM}}$ containing K1026, as a plant protection product (PPP), was accepted by the EU rapporteur member state (RMS) the United Kingdom. Regulations for biopesticide registration in the EU, at that time, came under the authority of the Directive 91/414/EEC, which was later repealed by Regulation (EC) No 1107/2009 in 2011. For K1026, if it was regulated as a GMO, the Dossier would need to follow Regulation EC 1829/2003 and Commission Implementing Regulation EU 503/2013 through the European Food Safety Authority (EFSA), which is now regulated under the Directive 2001/18/EC and Regulation (EU) No 546/2011.

After several months, the K1026 Dossier went through a preliminary assessment by the UK examiners, who raised 32 questions relating to clarifications, a lack of data and/or the inadequacy of some aspects of the dossier. Questions relating to physical, chemical and biological properties, toxicology, residues, environmental fate and behaviour, ecotoxicology and/or efficacy were raised. Some of the key questions that likely required further data related to:

1. The effects of agrocin 84 on a range of non-target organisms;

2. The amount of agrocin 84 in the end-product formulation;

3. The amount of the agrocin 84 antibiotic in batch samples and methods of analysis;

4. The effects of exposure to agrocin 84 on operators;

5. The development of agrocin 84 resistance in wild type agrobacteria;

6. The levels of K1026 in the air, water and in soils against background levels of agrobacteria;

7. The effects from use of K1026 on soil microorganisms levels;

8. Supporting information on risks to wildlife;

9. Supporting information on crop safety.

In the original submission to the EU for K1026 and its EUP, 44 supporting documents were provided to address many of the above concerns, including data showing that K1026 does not grow at $37^{\circ} \mathrm{C}$, the human body temperature. However, because the UK reviewers indicated that more data needed to be generated, at a considerable investment, the company withdrew its dossier and there has not been a new application to date. The review of 44 studies on K1026 by regulators in other jurisdictions resulted in the acceptance of the submitted background information and data contained in proprietary studies that addressed the safety of K1026 and agrocin 84. At the time of this EU submission, there had been over 30 years of commercial use of K84/K1026 in several non-European countries without any adverse reports on humans, animals, aquatic life, insects, non-target crops or the environment. The dossier contained publications by many researchers in EU countries who had reported their results showing the safety and effectiveness of these bacteria to control crown gall infections. Raio et al., reported in 2009 that $\mathrm{K} 84$ had been experimentally used in many European states for more than 30 years, and during this time, K84 had shown high efficacy in protecting several stone fruit trees and ornamentals [38].

K84 and K1026 are non-pathogenic, biovar 2 soil-borne agrobacteria, which have not shown any adverse effects in acute pathogenicity, toxicity (oral, dermal and pulmonary) or hypersensitivity studies, and agrocin 84 has no detectable mutagenic activity or cytotoxicity according to the Ames assay. Agrocin 84 is quite unstable at room temperature, suggesting that it has a short half-life in nature. Thus, while it may be extremely effective against certain types of phytopathogenic agrobacteria at the time of production, it is unlikely that residues of agrocin 84 will accumulate in the product or environment over time. Agrocin 84 is a mimic of certain agrocinopines that is are produced in plant galls and taken up by the pathogenic bacteria via a specific opine transporter system coded by their $\mathrm{Ti}$ 
plasmids. Hence, agrocin $84^{\prime}$ s mode of action is specific against only pathogenic agrobacteria that are able to catabolise these types of opines. Nevertheless, the EU's extensive questions about agrocin 84 and need for further non-target studies have seemingly set an uneconomical pathway for companies wanting to supply European nurseries with a safe, effective biocontrol agent against crown gall disease. In 2020, there remain no biopesticides registered containing K84 or K1026 under the EU Regulation No: $1107 / 2009$. Companies submitting dossiers for the registration of biopesticides in the EU face, on average, 65.7 months for approval, compared to 25.7 months in the US and lesser periods in other countries [39]. This review period could easily be much longer if additional data are required by the RMS and EFSA regulatory reviewers and when the dossier preparation time is considered. Clearly, there is an overestimation of the safety data needed on K84/K1026 and not enough emphasis placed on the significant losses plant nurseries incur due to crown gall infections. To our knowledge, K84 and K1026 EUPs have never been registered as biopesticides in any European country or in the EU.

Within the last 20 years, genetic analysis of the genome of Agrobacterium has resulted in several taxonomic name changes within biotypes of this bacterium. In the case of K84 and K1026, all government registrations are still in the name of Agrobacterium radiobacter, even though the taxonomically correct name is Rhizobium rhizogenes [40]. A submission to change the name for K1026 from A. radiobacter to $R$. rhizogenes with the APVMA has taken 22 months for this agency to issue an approval for the updated nomenclature. This lengthy process was mostly due to the bacterium reclassification in the Australian Poisons Standard before APVMA could approve the change.

Besides Australia and the USA, other countries that have registered K84 or K1026 products as biopesticides include Turkey (Ministry of Food, Agriculture and Livestock-K1026), Canada (Health Canada-K84), NZ (Ministry of Primary Industries, Agricultural Compounds and Veterinary Medicines (ACVM)—K84), Japan (Ministry of Agriculture, Forestry and Fisheries), South Africa (The South African National Pesticide Registration Authority) and Chile (Agricultural and Livestock Service/SAG -K84) (Figure 4). Many of these registrations have categorised K84 or K1026 agents as "fungicides", "biological fungicides", "bacteriocides" or microbial pesticides, which reflects the rigidity of the regulations for accommodating MPCAs and PPPs in their "chemistry"-orientated registration guidelines.

\subsection{Marketing and Distribution}

A thorough market assessment is essential before companies can proceed to the commercialisation of a biocontrol agent. Factors to review include the manufacturing and formulation costs, competing products, the size of the market, costs incurred through the regulatory process, Intellectual Property protection via patent/trademarks, the target crops involved, application options and others to develop a full analysis of what the return on investment might be. In the case of crown gall control, some unknowns included the potential size of the crown gall problem in various crops in propagation, the biotypes of the endemic pathogenic agrobacteria, grower acceptance of the product costs and production volume estimations, and, hence, the return on investment can be based on estimates of several criteria. The markets for K84 and K1026 are mainly restricted to nursery use, involving a few thousand to millions of propagating materials per nursery operation. Overall, however, the use of a biocontrol agent against crown gall is restricted to use on very small areas, and, in several cases, the supply of a product in any one country is limited to a single supplier. The nursery costs of using these biocontrol agents ranges from AUD 0.005-0.05 per seed, cutting or small seedling to about AUD $0.15-0.25$ per larger, bare-rooted transplant. Hence, the nursery costs are relatively low.

The marketing of K1026 has encountered some unique limitations that K84 has not due to it being a deletion mutant created by recombinant DNA technology. In Australia, the USA and Turkey, K1026 is not a regulated article under GMO legislation. However, not all regulatory agencies define this deletion the same way. For example, in Kenya, K1026 is required to be reviewed and regulated as a GMO under the Biosafety Act, 2009, because its Tra-gene deletions in pAgK1026 created "novel combinations of genetic material obtained through the use of modern biotechnology techniques". If the Kenyan 
National Biosafety Authority were to approve K1026 for environmental release, then the product label must state that it "contains a genetically modified Rhizobium rhizogenes strain K1026". Besides the issue of the public's perception of products containing GMOs, there is the expense and time that a company must allocate to get through these regulatory rulings. However, there is one market that K1026 will not get approval for, that being use in Australian organic farming. In a ruling in 2002 by the Australian Organic Produce Export Committee (OPEC), the reason K1026 was excluded from use under the National Standards was because:

"OPEC considered that the use of products with genes deleted as a result of a scientific intervention designed specifically to remove a gene would be inappropriate in organic farming and believed that their use could undermine consumer confidence in the certification of organic food exports. It, therefore, concluded that the definition of GMOs should extend to organisms of this type."

Besides this ruling, the Australian organic National Standards do not permit the use of gamma irradiation in the manufacture of products that would be ultimately used in organic and biodynamic agriculture systems. As K1026 is produced in peat that is pre-sterilised using gamma irradiation, its use also becomes precluded by this ruling. Both these reasons can be debated either way, but having the long-term advantage of K1026 verses the risk of K84's pAgK84 transfer and build-up of immunity among pathogenic agrobacteria, and the fact that growers can access pure cultures of live K1026 that do not introduce contaminant microorganisms, seems highly desirable and provides the best marketability and use of this biocontrol agent. The loss of the biocontrol of crown gall disease would cost the nursery industries significantly, so serious consideration to change these exemptions would, no doubt, be supported by most scientists and businesses that understand the importance of the Tra-gene deletions within pAgK1026.

\section{Conclusions}

The discovery, testing and commercialisation of an isolate of bacteria, code named K84, from soil near a peach crown gall in South Australia in 1970, has certainly seen its share of global interest and provided significant benefits to the nurseries where it has been used. The savings to the nursery industries from reduced losses due to crown gall disease must surely be in the tens of billions of dollars (AUD) over the past 48 years. However, K84's pathway from lab discovery and testing to a nursery propagator has had its challenges. Besides the formulation, manufacturing, technical, marketing and distribution aspects, the most significant challenge to the commercialisation of K84 or K1026 is successfully getting through the process of biopesticide registration with government agencies, especially for K1026 because of its $5.9 \mathrm{~kb}$ deletion within the transfer region of pAgK84. This most successful biocontrol technology has been globally under-utilised due to the enormous task of generating sufficient data to support biopesticide registration in some countries and by organic industries with incomprehensible rules. Commercial decisions to invest in the high cost of gaining government regulatory approvals for a product with a seasonal, relatively small-volume market has certainly limited access to these biocontrol agents in many countries. It has been suggested that one way to streamline and speed up the registration processes is through the international harmonization of a regulatory framework, e.g., for data requirements, fees, timelines, criteria for approval and risk assessments [31]. Another option considered by the EFSA is the approach using the principles of Qualified Presumption of Safety [41]. There is broad acceptance that, by whatever means, the streamlining and consolidation of international regulatory guidelines would seem a beneficial pathway for niche biocontrol products, such as for EUPs containing K84 or K1026, to stimulate interest in these technologies by large and/or SME companies. If broad acceptance of international harmonization is not achieved between regulatory jurisdictions, then many promising MPCAs or PPPs will remain unavailable options for agricultural production systems in some parts of the world. 
Author Contributions: A.K. contributed the science section of biological control of crown gall. G.B. contributed the case study of the challenges to commercialisation of the biological control agents strains K84 and K1026. All authors have read and agreed to the published version of the manuscript.

Funding: This research received no external funding.

Acknowledgments: We wish to thank John Reader for his contribution to the article and David Kerr for his help in its preparation. Additionally, we would like to thank Jim Barnes for the creation of the world map.

Conflicts of Interest: The authors declare no conflict of interest. Mention of trade names or commercial products in this article is solely for the purpose of providing supporting, historical information and does not imply recommendation or endorsement by the authors.

\section{References}

1. Chilton, M.-D.; Drummond, M.H.; Merlo, D.J.; Sciaky, D.; Montoya, A.L.; Gordon, M.P.; Nester, E.W. Stable incorporation of plasmid DNA into higher plant cells. Cell 1977, 11, 263-271. [CrossRef]

2. Lacroix, B.; Citovsky, V. Pathways of DNA transfer to plants from Agrobacterium tumefaciens and related bacterial species. Ann. Rev. Phytopath. 2019, 57, 231-251. [CrossRef] [PubMed]

3. Kerr, A. Biological control of crown gall: Seed inoculation. J. Appl. Bacteriol. 1972, 35, 493-497. [CrossRef]

4. Kerr, A. Biological control of crown gall. Australas. Plant. Pathol. 2015, 45, 15-18. [CrossRef]

5. Shim, J.-S.; Farrand, S.K.; Kerr, A. Biological control of crown gall: Construction and testing of new biocontrol agents. Phytopathology 1987, 77, 463-466. [CrossRef]

6. Jones, D.A.; Ryder, M.H.; Clare, B.G.; Farrand, S.K.; Kerr, A. Construction of a Tra- deletion mutant of pAgK84 to safeguard the biological control of crown gall. Mol. Gen. Genet. 1988, 212, 207-214. [CrossRef]

7. Kerr, A.; Htay, K. Biological control of crown gall through bacteriocin production. Physiol. Plant. Pathol. 1974, 4, 37-44. [CrossRef]

8. Murphy, P.J.; Tate, M.E.; Kerr, A. Substituents at N6 and C-5' control selective uptake and toxicity of the adenine nucleotide bacteriocin, agrocin 84 in Agrobacterium. Eur. J. Biochem. 1981, 115, 539-543. [CrossRef]

9. Reader, J.S.; Ordoukhanian, P.T.; Kim, J.G.; de Crecy-Lagard, V.; Hwang, I.; Farrand, S.; Schimmel, P. Major biocontrol of plant tumors targets tRNA synthetase. Science 2005, 309, 1533. [CrossRef]

10. Chopra, S.; Palencia, A.; Virus, C.; Tripathy, A.; Temple, B.R.; Valezquez-Campoy, A.; Cusack, S.; Reader, J.S. Plant tumour biocontrol agent employs a tRNA-dependent mechanism to inhibit leucyl-tRNA synthetase. Nat. Commun. 2013, 4, 1417. [CrossRef]

11. Ellis, J.G.; Kerr, A.; van Montagu, M.; Schell, J. Agrobacterium: Genetic studies on agrocin 84 production and the biological control of crown gall. Physiol. Plant. Pathol. 1979, 15, 311-319. [CrossRef]

12. Farrand, S.K.; Slota, J.E.; Shim, J.-S.; Kerr, A. Tn5 insertions in the agrocin 84 plasmid: The conjugal nature of pAgK84 and the locations of determinants for transfer and agrocin 84 production. Plasmid 1985, 13, $106-117$. [CrossRef]

13. Ryder, M.H.; Slota, J.E.; Scarim, A.; Farrand, S.K. Genetic analysis of agrocin 84 production and immunity in Agrobacterium spp. J. Bacteriol. 1987, 169, 4184-4189. [CrossRef] [PubMed]

14. Chopra, S.; Palencia, A.; Virus, C.; Schulwitz, S.; Temple, B.R.; Cusack, S.; Reader, J.S. Structural characterization of antibiotic self-immunity tRNA synthetase in plant tumour biocontrol agent. Nat. Commun. 2016, 7, 1-13. [CrossRef] [PubMed]

15. Petit, A.; Delhaye, S.; Tempe, J.; Morel, G. Recherches sur les guanidines des tissus de Crown Gall. Mise en evidence d'une relation biochemique specifique entre les souches d'Agrobacterium tumefaciens et les tumeurs qu'elles induisent. Physiol. Veg. 1970, 8, 205-213.

16. Ellis, J.G.; Murphy, P.J. Four new opines from crown gall tumours-their detection and properties. Mol. Gen. Genet. 1981, 181, 36-43. [CrossRef]

17. Ryder, M.H.; Tate, M.E.; Jones, G.P. Agrocinopine A, a tumor-inducing plasmid-coded enzyme product, is a phosphodiester of sucrose and L-arabinose. J. Biol. Chem. 1984, 259, 9704-9710.

18. Kim, H.; Farrand, S.K. Characterization of the acc operon from the nopaline-type plasmid pTiC58, which encodes utilization of agrocinopines A and B and susceptibility to agrocin 84. J. Bacteriol. 1997, 179, 7559-7572. [CrossRef] 
19. El Sahili, A.; Li, S.-Z.; Lang, J.; Virus, C.; Planamente, S.; Ahmar, M.; Guimaraes, B.; Aumont-Nicaise, M.; Vigouroux, A.; Soulère, L.; et al. A Pyranose-2-Phosphate Motif Is Responsible for Both Antibiotic Import and Quorum-Sensing Regulation in Agrobacterium tumefaciens. PLoS Pathog 2015, 11, e1005071. [CrossRef]

20. Donner, S.C.; Jones, D.A.; McClure, N.C.; Rosewarne, G.M.; Tate, M.E.; Kerr, A.; Fajardo, N.N.; Clare, B.G. Agrocin 434, a new plasmid encoded agrocin from the biocontrol Agrobacterium strains K84 and K1026, which inhibits biovar 2 agrobacteria. Physiol. Mol. Plant. Path. 1993, 42, 185-194. [CrossRef]

21. Burr, T.J.; Reid, C. Biological control of grape crown gall with Agrobacteriumn vitis strain F2/5. Am. J. Enol. Vitic. 1994, 45, 213-219.

22. Kawaguchi, A.; Inoeu, K.; Tamina, K.; Nita, M. Control of grapevine grown gall using nonpathogenic Rhizobium vitis strain ARK-1. Proc. Japan Acad. Ser. B Phys. Biol. Sci. 2017, 93, 547-560. [CrossRef]

23. Ellis, J.G. Can plant microbiome studies lead to effective biocontrol of plant diseases? Mol. Plant. Microbe Interact. 2017, 30, 190-193. [CrossRef]

24. Dewan, V.; Reader, J.; Forsyth, K.M. Role of aminoacyl tRNA synthetases in infectious diseases and targets for therapeutic development. Top. Curr. Chem. 2014, 344, 293-329. [PubMed]

25. Fravel, D.R. Commercialisation and implementation of biocontrol. Annu. Rev. Phytopathol. 2005, 43, 337-359. [CrossRef] [PubMed]

26. Regnault-Roger, C. Trends for Commercialization of Biocontrol Agent (Biopesticide) Products. Plant Def. Biol. Control. 2011, 139-160.

27. Stewart, A. Commercial biocontrol: Reality or fantasy? Australas. Plant Pathol. 2001, 30, 127-131. [CrossRef]

28. Kerr, A.; Clare, B.G.; Ryder, M.H.; Farrand, S. Agrobacterium radiobacter K84 Carrying Transfer-Deficient pAgK84 Plasmid. U.S. Patent 5,354,684, 11 October 1994.

29. Chandler, D.; Bailey, A.S.; Tatchell, G.M.; Davidson, G.; Greaves, J.; Grant, W.P. The development, regulation and use of biopesticides for integrated pest management. Philos Trans. R Soc. Lond. B Biol. Sci. 2011, 366, 1987-1998. [CrossRef]

30. OECD. Available online: https://www.oecd.org/env/ehs/pesticides-biocides/data-for-biopesticideregistration.htm (accessed on 1 August 2020).

31. Kabuluk, J.T.; Svircev, A.M.; Goettel, M.S.; Woo, S.G. Use and Regulation of Microbial Pesticides in Representative Jurisdictions Worldwide. 2010, p. 99. Available online: https://www.researchgate.net/profile/ Nguya_Maniania/publication/297758802_Microbial_Regulation-Goettel_et_al_2010-Todd-Goettel/links/ 56e2e9da08ae387a2483a704/Microbial-Regulation-Goettel-et-al-2010-Todd-Goettel.pdf (accessed on 1 August 2020).

32. Rhizobium rhizogenes. In Proceedings of the Invasive Species Compendium, Wallingford, UK, 17 March 2020; Available online: www.cabi.org/isc/datasheet/3743 (accessed on 2 December 2019).

33. Gene Technology Act. Available online: http://www.legistlation.gov.au/Details/C2016C00792 (accessed on 1 August 2020).

34. Gene Technology Regulations. Available online: http://www.legislation.gov.au/Details/F2019C00781 (accessed on 1 August 2020).

35. Cook, R.J.; Bruckart, W.L.; Coulson, J.R.; Goettel, M.S.; Humber, R.A.; Lumsden, R.D.; Maddox, J.V.; McManus, M.L.; Moore, L.; Meyer, S.F.; et al. Safety of Microorganisms Intended for Pest and Plant Disease Control: A Framework for Scientific Evaluation. Biol. Control. 1996, 7, 333-351. [CrossRef]

36. USA EPA. Available online: https://www.epa.gov/pesticide-registration/biopesticide-registration (accessed on 1 August 2020).

37. USA EPA. Agrobacterium radiobacter strains K84/Kerr-84 and K1026 Registration Review Case 4101. Available online: https://www.regulations.gov (accessed on 29 March 2010).

38. Raio, A.; Peluso, R.; Puopolo, G.; Zoina, A. Evidence of pAgK84 transfer from Agrobacterium rhizogenes K84 to natural pathogenic Agrobacterium spp. in an Italian peach nursery. Plant. Pathol. 2009, 58, 745-753. [CrossRef]

39. Frederiks, C.; Wesseler, J. A comparison of the EU and US regulatory frameworks for the active substance registration of microbial biological control agents Pest. In Management Science; John \& Wiley \& Sons Ltd.: Hoboken, NJ, USA, 2018. 
40. Lindstrom, K.; Young, J.P.W. Subcommittee on the taxonomy of Agrobacterium and Rhizobium. Int. J. Syst. Evolut. Microbiol. 2011, 61, 3089-3093.

41. Andreoletti, O. European Food Safety Authority Scientific Committee Scientific opinion: The maintenance of the list of QPS microorganisms intentionally added to food or feed. Scientific Opinion of the Panel on biological Hazards (Question No EFSA-Q-2008-006). EFSA J. 2008, 923, 1-48.

(C) 2020 by the authors. Licensee MDPI, Basel, Switzerland. This article is an open access article distributed under the terms and conditions of the Creative Commons Attribution (CC BY) license (http://creativecommons.org/licenses/by/4.0/). 